\title{
HVMANITAS
}

\section{A linhagem da Rainha Santa Isabel segundo De Vita et Moribus Beatae Elisabethae Lusitaniae Reginae de Pedro João Perpinhão}

Autor(es): $\quad$ Toipa, Helena Costa

Publicado por: Imprensa da Universidade de Coimbra

URL

persistente:

URI:http://hdl.handle.net/10316.2/35110

DOI:

DOI:http://dx.doi.org/10.14195/2183-1718_66_19

Accessed : $\quad$ 26-Apr-2023 14:52:38

A navegação consulta e descarregamento dos títulos inseridos nas Bibliotecas Digitais UC Digitalis, UC Pombalina e UC Impactum, pressupõem a aceitação plena e sem reservas dos Termos e Condições de Uso destas Bibliotecas Digitais, disponíveis em https://digitalis.uc.pt/pt-pt/termos.

Conforme exposto nos referidos Termos e Condições de Uso, o descarregamento de títulos de acesso restrito requer uma licença válida de autorização devendo o utilizador aceder ao(s) documento(s) a partir de um endereço de IP da instituição detentora da supramencionada licença.

Ao utilizador é apenas permitido o descarregamento para uso pessoal, pelo que o emprego do(s) título(s) descarregado(s) para outro fim, designadamente comercial, carece de autorização do respetivo autor ou editor da obra.

Na medida em que todas as obras da UC Digitalis se encontram protegidas pelo Código do Direito de Autor e Direitos Conexos e demais legislação aplicável, toda a cópia, parcial ou total, deste documento, nos casos em que é legalmente admitida, deverá conter ou fazer-se acompanhar por este aviso.

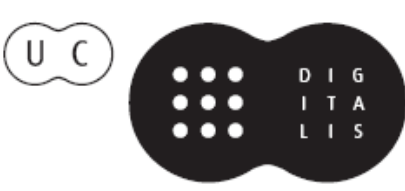


humanitas

Vol. LXVI

2014

IMPRENSA DA UNIVERSIDADE DE COIMBRA

COIMBRA UNIVERSITY PRESS 


\title{
A linhagem da Rainha Santa Isabel Segundo De Vita et Moribus Beatae Elisabethae Lusitaniae Reginae de Pedro João Perpinhão
}

\author{
THE LINEAGE of QueEN SAINT ELISABETH, ACCORDING TO \\ De Vita et Moribus Beatae Elisabethae Lusitaniae \\ Reginae by Pedro Jỗo Perpinhão
}

\author{
Helena Costa Toipa \\ Centro de Estudos Clássicos e Humanísticos da Universidade de Coimbra \\ helenacosta64@gmail.com
}

\begin{abstract}
Resumo
Pedro Perpinhão, padre jesuíta residente em Portugal entre 1551 e 1561, compôs uma biografia sobre a rainha Santa Isabel de Portugal, em latim, que era a mais completa escrita até à data, De Vita et Moribus Beatae Elisabethae Lusitaniae Reginae. Nela, começa por apresentar os antecedentes familiares da Rainha, manifestando, neste processo, a sua posição sobre o labor histórico: por um lado, preocupação em transmitir a verdade dos factos, que investiga nas fontes escritas que refere frequentemente, e em evitar a parcialidade, apresentando versões diferentes do mesmo acontecimento; por outro, a concepção da História como manancial de exemplos a evitar ou a seguir, condenando ou louvando respectivamente os comportamento das personalidades históricas.

Palavras chave: Rainha Santa Isabel, Pedro Perpinhão, Historiografia hagiográfica.

\footnotetext{
Abstract

Pedro Perpinhão, Jesuit priest who lived in Portugal between 1551 and 1561, wrote a biography in Latin about Saint Elisabeth, Queen of Portugal, De Vita et Moribus Beatae Elisabethae Lusitaniae Reginae, that was the most complete ever written at the
} 
time. At the beginning of the biography, he presents her family history, revealing in this process his point of view on historical writing: the necessity to convey the truth, sought in the written sources to which he often referred, and in avoiding partiality, exhibiting different versions of the facts; he also sees History as a source of examples that must be avoided or pursued, by condemning or praising, historical personalities.

Key words: Saint Elisabeth of Portugal, Pedro Perpinhão, hagiographical historiography.

Ao propor-se narrar a vida e costumes da bem-aventurada rainha D. Isabel de Aragão, o padre jesuíta valenciano Pedro João Perpinhão, que viveu e trabalhou em Portugal, como professor do Colégio das Artes e do Colégio do Espírito Santo, investigador e orador, entre 1551 e $1561^{1}$, estabeleceu começar por apresentar os antecedentes familiares da sua biografada, remontando aos seus tetravós, para relembrar os seus muitos e variados feitos, mais ou menos ilustres, já há muito afastados da memória dos homens. Numa óptica de obediência escrupulosa à verdade, não omite qualquer pormenor, ilustre ou menos dignificante, como também não poupa críticas ou elogios quando considera que são merecidos ${ }^{2}$.

A incumbência de Perpinhão de se dedicar ao estudo e à divulgação da vida e obra desta rainha adveio-lhe das decisões régias de D. João III, de 1556, no sentido de incrementar o culto desta sua antepassada, dando continuidade a um processo conducente à sua eventual canonização que começara logo após a sua morte ${ }^{3}$. Assim, o rei decretara que, no Colégio das Artes de Coimbra, todos os anos, no dia 4 de Julho, um dos seus docentes pronunciasse uma oração de louvor à Rainha, a que deveria assistir também a Universidade ${ }^{4}$; Perpinhão foi o primeiro orador escolhido, para os três anos seguintes, 1557, 1558, 1559, de que resultaram Laudationis

1 Sobre a vida e obra de Pedro João Perpinhão, consulte-se Gaudeau 1891; Lazeri 1749, Toipa, 2011.

2 Esta posição de Perpinhão assemelha-se à formulada por Damião de Góis, no Prólogo da Crónica do Felicíssimo rei D. Manuel, quando afirma "ho mais substançial que no screver das Chronicas se requere (...) hé com verdade dar a cada hum o louvor ou a reprehensam que mereçe”. Sobre o tratamento da História pelos humanistas, cf. Soares 1992: 153-169.

3 Sobre a evolução do culto da Rainha Santa Isabel, consulte-se Vasconcelos 1891-1894.

4 Teixeira 1899: 398-399. 
in Beatam Elisabetham Lusitaniae Reginam libri tres ${ }^{5}$. Ordenara também ao provincial dos conventuais que procurasse "de auer em hum liuro toda a lenda da dita $\mathrm{R}^{\mathrm{a}} \mathrm{E}$ todos os milagres que deus por ella fez e faz de que ha memoria autentica no conuento de sta crara e faça treladar fielmente o liuro de sua historia por enteyro ${ }^{6 "}$. Perpinhão acatou esta determinação do rei e compôs a biografia De Vita et Moribus Beatae Elisabethae Lusitaniae Reginae libri tres ${ }^{7}$, entre 1556 e 1561, mas que foi publicada apenas em 1609, em Colónia, estando, no entanto, registada nos documentos dos jesuítas do Colégio das Artes, como se pode verificar pela consulta do códice 993 da Biblioteca Geral da Universidade de Coimbra, Rerum scholasticarum quae a patribus ac fratribus huius Conimbricensis Collegii scripta sunt tomus secundus, ff. 5r-54v.

D. Isabel de Aragão era oriunda de uma linhagem de reis e de imperadores. À materna, Perpinhão atribui-lhe uma forte antipatia popular, pelos actos de crueldade e perfídia; a paterna, se bem que marcada pelo desrespeito pelos laços matrimoniais e por alguns comportamentos menos dignos, fez-se valer maioritariamente pela piedade e mesmo pela santidade de alguns dos seus membros. Os exemplos da família materna são de evitar, os da paterna de louvar e imitar; em qualquer dos casos, porém, mesmo na materna, não há qualquer rainha mencionada que lhe mereça a menor crítica; elas são, pelo contrário, geralmente louvadas pelos seus papéis na história dos seus reinos.

Do lado materno da Rainha, Perpinhão começa a traçar a árvore genealógica a partir do seu tetravô, Frederico I, Barba Roxa (1122-1190), $3^{\circ}$ duque de Suábia, rei de Itália (1155-1190) e $1^{\circ}$ imperador do Sacro Império Romano-Germânico (1152-1190), tendo sucedido ao pai como duque da Suábia e, ao tio Conrado III, como rei da Alemanha. Desejando restaurar as glórias do Império Romano, tratou de consolidar a posição imperial tanto na Germânia como na península Itálica. Apesar de continuados conflitos com o papado, nomeadamente com o Papa Alexandre III, conseguiu finalmente impor a sua autoridade sobre este e assegurou a influência alemã na Europa Ocidental. Depois de abdicar em favor do filho Henrique, morreu ao atravessar o rio Cythos, na Cilícia, quando se dirigia à Palestina, no âmbito da $3^{\text {a }}$ Cruzada. Perpinhão pronuncia-se sucintamente sobre esta figura,

5 Perpiniani $17492^{\circ} 1-162$.

6 Vasconcelos 1891-94: $2^{\circ} 63$.

7 Perpiniani 1749: $2^{\circ} 163-301$. 
destacando os conflitos que manteve com o Papa e a causa da sua morte, de que terá encontrado versões divergentes nos historiadores consultados; como faz recorrentemente nesta sua biografia, apresenta as duas versões:

O Imperador Frederico, o primeiro deste nome a alcançar o supremo poder, normalmente designado Enobarbo, depois do regresso às boas-graças do Pontífice Máximo Alexandre III, que combatera durante muito tempo com um ódio feroz, protagonizando feitos grandiosos na Ásia, ao entrar num rio cheio de turbilhões, fosse para se banhar, fosse para o atravessar, deixara, com uma morte repentina, indigna de tamanho poder, o luto ao exército e a fuga ao vencedor. ${ }^{8}$

Sucedeu-lhe seu filho legítimo, Henrique VI de Hohenstaufen (1165-1197), Imperador do Sacro Império Romano-Germânico (1190-1197). Este assumiu a governação quando o pai partiu em Cruzada para a Terra Santa e sucedeu-lhe no trono, quando da sua morte, no ano seguinte. Participou na vida cultural do seu tempo, mas era desprovido de escrúpulos e não olhava a meios para atingir os seus fins, pelo que recebeu o cognome de Cruel. Casou com Constança de Hauteville, princesa da Sicília, filha legítima de Rogério I, rei de Nápoles e da Sicília, da qual lhe adveio o poder sobre esta região. Com efeito, tendo-se candidatado ao trono da Sicília, por morte de seu sobrinho Guilherme II, Constança fora inicialmente rejeitada pelos sicilianos, que concederam o trono ao seu sobrinho natural, Tancredo; Henrique VI, defendendo os interesses da esposa, conquistou a Sicília e acabou por impor a sua autoridade; à sua morte, o seu trono passou para seu filho. Estes são os trisavós maternos de Santa Isabel. Sobre esta princesa, Perpinhão tem palavras de apreço, pois refere que teve prudência e engenho suficiente para salvaguardar a posição do filho, o futuro imperador Frederico II, na sucessão do pai. Quanto a Henrique VI, parece ter governado com equidade, mas acabou por entrar em conflito com o Papa e morreu excomungado.

Perpinhão refere estes factos, nomeadamente o de ter morrido excomungado. Numa manifestação da sua posição característica de apresentar duas ou mais versões da mesma realidade, recolhidas em fontes diversas, quando é o caso, Perpinhão refere aqui duas informações: a que recolhera de que Constança casara com Henrique já em idade muito adulta e depois de ter professado, tendo sido para o efeito dispensada dos seus votos pelo

8 Perpiniani 1749: $2^{\circ} 169$. 
Papa; e a informação de que o casamento fora arranjado por seu pai e casara ainda nova:

Henrique, seu filho, administrando já entre os Germanos a totalidade dos assuntos, chamado à Itália e vencido Tancredo, filho da concubina de Rogério, que se apressara a tomar posse do Reino de Nápoles e Sicília, sem dono e vazio, depois da morte de Guilherme, tomou conta da situação, por suprema vontade do Pontífice Máximo. Parece ter governado com muita equidade para cá e para lá do estreito de Sicília, uma vez que tinha tomado como esposa Constança, filha do mesmo Rogério, nascida de casamento legítimo, quer tivesse casado com ela em anos anteriores, em idade florescente, por iniciativa de seu pai Frederico, quer, nascida já há cinquenta anos e consagrada antes a Cristo, em cerimónia pública, lhe tivesse sido dada em casamento, quando chegou, pelo Pontífice Máximo, depois de a libertar do voto de religião. Mas, em breve, porque, seguindo o exemplo do pai, hostilizava a causa pontifícia, deixou a vida, impedido por Inocêncio de aceder aos sagrados altares e templos ${ }^{9}$,

Segue-se Frederico II (1194-1250), Imperador do Sacro Império Romano-Germânico (1220-1250) e rei da Sicília (1197-1250), bisavô de Santa Isabel. Era filho de Henrique VI de Hohenstaufen, que morreu quando ele tinha três anos, e de Constança de Hauteville acima referidos. A mãe atraiu para o filho o favor do Papa Inocêncio III, concedendo muitos privilégios à Santa Sé, e quando Constança morreu, o Papa tomou-o sob sua protecção, educou-o e coroou-o. Não saiu à mãe, em prudência e ponderação, mas, antes, seguiu o exemplo da linha masculina do pai e do avô os quais, na opinião de Perpinhão, ultrapassou em desprezo e ferocidade de costumes. Perpinhão traça-lhe um perfil com as mesmas pinceladas com que, entre os latinos, Salústio pintou Catilina: um governante com algumas qualidades, mas com uma quantidade semelhante de defeitos. E de facto, embora desleal, pérfido e cheio de vícios, falava várias línguas, fazia versos em italiano e escrevia cartas em latim; compôs o tratado "De arte uenandi cum auibus"; desenvolveu os estudos na Universidade de Pádua, Bolonha, Salerno e fundou a Universidade de Nápoles; coleccionava manuscritos preciosos e mandou traduzir para latim obras de Aristóteles, Ptolomeu e Galeno. Ao longo da sua vida, manteve contínuas divergências com o papado, pelo que foi excomungado, em 1239, deposto pelo Papa Inocêncio

9 Perpiniani 1749: $2^{\circ}$ 169-170. 
IV, em 1245 e morreu em 1250, deixando o Império dividido, de modo que os seus sucessores tiveram dificuldade em impor-se. Seguindo a linha dos historiadores antigos e dos humanistas, de que a história é manancial de exemplos a seguir ou a evitar, a louvar e a criticar, respectivamente, pois é magistra uitae ${ }^{10}$, Perpinhão afirma que Frederico II teve o castigo que merecia pelos seus actos ao longo da vida, ao ser assassinado pelo próprio filho, Manfredo:

Constança, senhora prudente, conseguiu o reino para seu filho Frederico que, após a morte da mãe, declarado Imperador, parecia, a princípio, abraçar com grande interesse a dignidade pontifícia; mas, logo depois, mudando a sua disposição, ultrapassou o seu pai e o seu avô, com o desprezo e ferocidade de costumes. Tinha um talento superior àquele, uma grande robustez de corpo, uma singular paciência nos sofrimentos, uma exímia prudência nas questões militares, um ardente interesse pelo conhecimento, dominando quase de igual forma as línguas grega, latina, germânica, gaulesa e árabe, e uma munificência digna de um Imperador.

Mas, enormes vícios igualavam as tão grandes virtudes deste homem. Levava uma vida escandalosa e impura, tinha uma ambição muito desenfreada de glória e poder, uma desumana crueldade para com os vencidos, que deformava quase toda a Itália com uma triste devastação e uma furiosa contenda entre as partes; a ligação com os sarracenos era mais intensa do que convinha a um Imperador escolhido por toda a República Cristã, aos quais, chamando-os a Tunes, concedera Lucéria, uma cidade antiquíssima da Apúlia; era de uma maldade quase inacreditável para com os Pontífices Romanos, tinha-lhes tamanho ódio que àqueles íntimos com os quais costumava privar da forma mais familiar, a esses mesmos, adeptos do Pontífice Máximo, considerava inimigos capitais ${ }^{11}$

Por causa destas situações, como the fossem interditados, e não apenas uma vez, os sacramentos e o contacto dos actos piedosos, retirados os seus poderes, sofreu um castigo digno da sua impiedade e loucura, por acção do filho ilegítimo Manfredo. Com efeito, crê-se que o jovem, desejoso do dinheiro do pai e de se apoderar do poder, terá estrangulado, no próprio leito, o velho, debilitado há muito tempo por doença grave ${ }^{12}$.

10 Na célebre expressão de Cícero, De Oratore, 2.9.36: "Historia uero testis temporum, lux ueritatis, uita memoriae, magistra uitae, nuntia uetustatis".

11 Na elaboração deste retrato, Perpinhão inspirou-se no retrato de Catilina feito por Salústio em De coniuratione Catilinae.

12 Perpiniani 1749: $2^{\circ}$ 170-171. 
Sucedeu-lhe Manfredo (1232-1266), seu filho ilegítimo, que era suspeito de ter assassinado o pai, bem como o seu meio-irmão, Conrado IV (1228-1254), o filho legítimo e herdeiro de Frederico II. Manfredo era príncipe de Tarento, e foi rei da Sicília e Nápoles, depois de expulsar as tropas do Papa Alexandre IV; no entanto o Papa excomungou-o e o reino pretendido da Sicília acabou por ser oferecido a Carlos d'Anjou. Foi poeta e protegeu artistas. A opinião de Perpinhão é francamente desfavorável a esta figura e volta a insistir na afirmação de que os maus actos são punidos ainda em vida, mais tarde ou mais cedo. Manfredo era filho ilegítimo de Frederico II, tão mau como ele, e é aqui acusado de ter apressado a morte do pai, bem como de ter providenciado a do irmão, Conrado IV, envenenando-o. Este fora herdeiro do trono em 1237, mas derrotado por Guilherme de Holanda, renunciou à Germânia e retirou-se para o seu reino da Sicília, em 1251, tendo morrido repentinamente, de acordo com os relatos históricos.

O sobrinho, Conradino (1252-1268), filho de Conrado, parece ter escapado graças à argúcia e previdência da mãe, Isabel de Baviera, e, órfão de pai, foi criado com esta na corte do tio, Luís da Baviera. Manfredo ignorou os direitos do sobrinho e fez-se coroar rei da Sicília, em 1258, impôs-se às cidades do norte de Itália e firmou uma aliança com Aragão, casando sua filha Constança com o futuro Pedro III; mas não tinha o apoio do Papa Urbano IV que frequentemente afrontara e que atribuiu o trono da Sicília a Carlos d'Anjou, irmão do rei de França, Luís. Foi em confronto com este que, aliado aos sarracenos, morreu em Benavento, em 1266. Perpinhão manifesta-se da seguinte forma sobre estas figuras:

Com efeito, crê-se que o jovem, desejoso do dinheiro do pai e de se apoderar do poder, terá estrangulado, no próprio leito, o velho, debilitado há muito tempo por doença grave. Da mesma forma, ao irmão Conrado (esta foi, com efeito, uma suspeita muito forte), a quem cabia a herança do reino paterno e avoengo, suprimiu-o com veneno. E teria feito desaparecer, pelo mesmo crime, o seu pequeno filho Conradino, se a sua mãe, senhora muito sagaz, pressentindo os planos do cunhado, não tivesse frustrado as artes ocultas do inimigo doméstico, com um artifício igual.

Enganou Inocêncio IV que voltava da Gália, simulando boas relações de amizade; duas vezes caiu sobre o exército pontifício; de forma enganosa, convenceu que Conradino estava morto e, ocupado o reino sarraceno, chamava os militares a Itália para a ruína e devastação. Mas Deus, na verdade, não permitindo que a crueldade unida à impiedade do parricida ficassem impunes e livres, vingou, quanto mais tardiamente, tanto mais 
gravemente, a perversidade continuada. Carlos, Conde da Provença (parte da Gália Narbonense), enviado pelo Sumo Pontífice para a Itália, confrontou aquele monstro cheio de perfídias, o qual vencido com os seus sarracenos em grande combate, junto de Benavento, e atingido por muitas feridas, tal como convém que sejam os finais daqueles que, para satisfazer o desejo de dominar, se aliam a auxiliares inimigos do nome cristão, na própria frente de batalha entregou miseravelmente a terrível alma, contaminada pelo assassínio do pai e do irmão, e perdeu, ao mesmo tempo, a vida e o reino ${ }^{13}$

\section{Quanto a Conradino, de que Perpinhão fala pouco, ao chegar à} maioridade, armou um exército e entrou na Itália, para reclamar o seu

\section{Perpiniani 1749: 2o 171-172.}

Opinião de Perpinhão frequente nos seus textos: os maus actos são punidos ainda em vida, mais tarde ou mais cedo. Manfredo é aqui acusado de ter apressado a morte do pai, bem como a de ter providenciado a do irmão, envenenando-o. Rui de Pina, na Chronica delRey Dom Diniz, 1977: 225-26, também o acusa deste crime e parece ser a fonte de Perpinhão:

Este Rey D. Pedro seu filho deste nome ho quarto, e dos Reys Daraguam ho onzeno, contra vontade de seu pay cazou cõ Dona Costança, filha delRey Manfreu, que foy dambas as Cezilias, filho bastardo de Frederiquo II, Emperador Dalamanha, e Rey de Cezilia, e de Napoles, que foy Erege, e máo homem e cruel, e perseguidor de Egreja, assi como fora seu avoo, ho outro Frederiquo, que dicerão Barbarroxa, ho qual Emperador Federiquo II, sendo doente em Fruelmela, Luguar do Reyno Dapulha por consentimento de hum seu Camareyro foy afoguado, e morto por este seu filho Manfreu, que se chamava Principe de Tarento, para loguo aver como ouve, seus tezouros, que eram muy grandes, e esta abominavel maldade fez por tal que em algum testamento, que ho pay podera fazer, nom despozesse de suas riquezas ho contrayro do que dezejava.

E deste Emperador fiquou hum filho legitimo, que chamavam Conrado, que era em Alemanha, e vindo para Napoles de Cezilia, que direytamente lhe pertencia também Manfreu seu irmão em hum pastel ho fez matar com peçonha, $e$ deste Conrado fiquára hum filho menino erdeyro dito Conradino, que em mistura de certos prezentes, e joyas também seu tio ho quizera matar cõ peçonha, mas ha Raynha mãy do menino como muy prudente, e receosa das manhas de Manfreu aprezentou em luguar do filho outro menino em tudo conforme, que por elle loguo morreo, ho qual Manfreu por morte de Conrado seu irmão com as muitas riquezas, que tinha occupou loguo, e ouve o Reyno de Cezilia, que sendo sobre esso pelo Papa Alexandre escommungado, e perseguido com exercito para que deixasse ho Reyno, elle por sua ajuda meteo em Italia muitos Mouros de Tunes, e Dafriqua cõ que desbaratou ha gente do Papa, e fez em Italia grandes destoições, e levou della grandes despojos. 
trono, em 1268, mas foi derrotado por Carlos d'Anjou e decapitado em Nápoles, no mesmo ano ${ }^{14}$.

Em 1282, os sicilianos revoltaram-se contra os franceses (Vésperas Sicilianas) e entregaram o trono da Sicília a D. Pedro, casado com D. Constança de Hohenstaufen, filha de Manfredo e neta de Frederico II; esta foi, pois, rainha de Aragão (1276-1302) e da Sicília (1282-1302). D. Constança é apresentada por Perpinhão como uma senhora prudente e moderada, que soube aplicar a justiça nos seus domínios; com a sua actuação, impediu a morte sumária sem julgamento de Carlos, o Coxo, filho de Carlos de Anjou, quando os sicilianos se vingaram dos franceses. Por seu intermédio, a sua família voltou às boas graças do Papa.

Nascida deste pai, destes avós e antepassados, Constança, mãe da nossa Isabel, foi de não mediocre moderação e prudência. A sua chegada à Sicília renovou a memória daquela ilustre Constança, cuja saudade ainda dominava os espíritos dos insulares. E, assim, como os Sicilianos se preparassem para matar Carlos, o Coxo, filho do anterior e herdeiro do trono, capturado por Rogério Láuria, comandante da frota aragonesa, queimados já, na mesma prisão, os restantes cativos, ela aplacou a multidão furiosa de dor e enviou a nobre presa para Espanha, para o rei. E, depois da morte do marido, estabelecida a paz com o gaulês, já antes retirado do cárcere, dirigiu-se, com o filho Jaime, rei de Aragão e Sicília ao Sumo Pontífice Bonifácio VIII, pelo qual humanissimamente aceites, foram restituídos à comunidade dos piedosos, de cujos hábitos e assembleia tinham sido excluídos havia tanto tempo ${ }^{15}$.

14 Estas informações sobre Conradino e o final de Manfredo, poderá Perpinhão tê-las colhido em Rui de Pina 1977: 226:

Pelo qual ho Papa Urbano IV, enviou em França chamar ha Carlo irmão delRey S. Luis ha quem fez Alferes da Egreja, e lhe deu hos Reynos de Napoles, $e$ de Cezilia, porque hos cobrasse de Manfreu, que tiranamente os usurpava, e Carlo ajuntou muita gente, e com ajuda do Papa ouve batalha com Manfreu junto de Benavente em Italia onde ho dito Manfreu foi morto, de que hos Reynos de Cezilia, e de Napoles fiquaram logo pacifiquos ha Carlo, especialmente, que depois da morte de Manfreu tambem Carlo matou em outra batalha ho Conradino neto de Frederiquo, ho que Manfreu quizera nas joyas matar, porque com grande exercito veo contra Carlo para cobrar hos Reynos que dizia lhe pertencerem de direyto, $e$ na contenda foy morto (...)

Em 1282, os sicilianos revoltaram-se contra os franceses (Vésperas Sicilianas) e entregaram o trono da Sicília a D. Pedro, casado com D. Constança, filha de Manfredo e neta 
Sobre o lado feminino da linhagem materna de Santa Isabel, Perpinhão só tece elogios, não aponta defeitos: as rainhas são previdentes, sagazes, moderadas, agem com prudência e ponderação; eventualmente, têm até vocação para a vida religiosa. Dos homens, nenhum se distingue pelo bom carácter; os seus exemplos são, pois, absolutamente de evitar.

Quanto à linhagem paterna, Perpinhão remonta ao bisavô de D. Isabel, D. Pedro II, filho de D. Afonso II de Aragão e de D. Sancha de Castela; foi rei de Aragão e senhor do principado da Catalunha e do condado de Montpellier, pelo seu casamento com Maria de Montpellier. Entre outros feitos, destacou-se na batalha de Navas de Tolosa, contra os Almóadas. Morreu na batalha de Muret, em 1213, lutando contra o exército do chefe dos cruzados, Simão de Monfort, enviado pelo Papa para combater o desenvolvimento e afirmação da heresia cátara nos seus territórios. Deixou órfão seu filho Jaime, com 5 anos de idade, que estava, então, aos cuidados do próprio Simão de Monfort, com cuja filha estava planeado casar-se. As palavras de Perpinhão também não são muito abonatórias para esta figura; lembra sucintamente alguns episódios em que se ilustrou, mas critica a forma como morreu; não refere claramente o seu desprezo pelo tálamo conjugal, nem a artimanha usada pela rainha, D.

de Frederico II. No conflito que opôs D. Pedro III de Aragão e sua esposa, D. Constança, a quem caberia o trono da Sicília, a Carlos de Anjou, surgiu esta situação, contada por Perpinhão de forma elíptica, mas bastante desenvolvida em Rui de Pina. Carlos de Anjou deixara seu filho por governante da Sicília, mas este foi capturado por um Almirante dos reis aragoneses, Rogério de Láuria, o que causou o desgosto e morte do pai e a completa sublevação dos sicilianos contra os franceses. Rui de Pina 1977: 228:

(...) hos de Mecina, porque eram por este caso apertados pelo Papa com grandes escõmunhões, e antreditos sabendo ha morte delRey Carlo por mais sua vingança se foram ahos carceres, onde estavam hos Francezes para hos matarem, e porque os prezos eram homens, e bons Cavalleyros se poseram em defençam, $e$ resistencia, e foram dos Cezilianos nos mesmos carceres mortos sem piedade, $e$ queymados, e assi quizeram fazer aho Principe Carlo, se ha Rainha Dona Costança molher delRey D. Pedro, que ha esse tempo era em Cezilia, lhe nom valera, porque estranhou fazerse tam crua justiça, sem mandado, nem autoridade delRey D. Pedro seu marido, e dally concordaram, que Carlo fosse levado preso, como foy Araguam, onde era, e avendo quatro annos, que ho dito Carlo era prezo depois da morte delRey D. Pedro, Reynando em Araguam ElRey D. Affonso deu filho, foy por meio delRey D. Duarte Dingraterra solto sobre ha refens (...). E por esto, $e$ por cazamentos que depois antre elles se fizeram fiquou ahos Reys de Araguam ho direyto no Reyno de Cezilia (...) 
Maria de Montpellier, para conceber o seu único filho; esse esclarecimento encontra-se em Rui de Pina, na Chronica delRey Dom Diniz, fonte de Perpinhão, que utilizará a informação quando falar do filho:

O rei Pedro de Aragão (com efeito, os antigos Celtiberos, respirando um pouco já a Hispânia sobre as almas dos bárbaros, começaram a ser chamados aragoneses), repito, o rei Pedro, deste nome o segundo destes povos, varão de espírito ilustre e invencível, digno de ter caído lutando por causa melhor, cuja extraordinária força de corpo e de alma brilhou acima de tudo naquela memorável batalha travada por três reis da Hispânia, contra o rei maometano, rei de cada uma das Mauritânias e da Bética, no maciço montanhoso da Bética, teve um único filho da esposa já numa idade bem avançada ${ }^{16}$.

Mas é ao avô de D. Isabel, com quem ela conviveu nos primeiros anos da sua vida, que Perpinhão dá mais destaque, aludindo às peripécias da sua gestação e escolha do nome, com assistência divina, que já auguravam a sua actividade em defesa da fé, às suas conquistas e à sua vida de santidade. Trata-se de Jaime I (1208-1276), o Conquistador, nome que lhe advém do facto de ter conquistado Maiorca (em 1229), Menorca (em 1231), Ibiza e Formentera (em 1235); com estas conquistas, expulsou os muçulmanos destas ilhas e acabou com a pirataria, dando início à expansão mediterrânica da coroa aragonesa; em 1238, conquistou Valência, em 1265, Múrcia e, em 1273, Ceuta. O favor que dispensava aos bastardos originou protestos dos nobres e dos filhos, legítimos e ilegítimos, facto que Perpinhão não refere, atribuindo o mau relacionamento que existia entre pai e filho ao facto de este ter casado sem a sua aprovação com Constança, filha do iníquo Manfredo. Dividiu o poder pelos seus filhos Pedro e Jaime: o primeiro herdou os territórios de Valência, Aragão e Catalunha; o segundo, Montpellier e as Baleares. As palavras de Perpinhão são apenas de elogio e admiração, apresentando-o como modelo de virtudes e até de santidade, e atribuindo-lhe alguns milagres:

Este, contra a opinião de quase todos, contra a superior expectativa dos cidadãos, com um plano inusitado da mãe, não nasceu sem a assistência divina, para castigar os inimigos da religião cristã e exterminá-los nas fronteiras da Hispânia citerior, até pelo canto dos sacerdotes ignorantes do que acontecera, revelador de que seria pública salvação do reino; recebeu,

16 Perpiniani 1749: $2^{\circ}$ 172-173. 
de forma quase divina concedido, o nome do Apóstolo Tiago, que os reis hispânicos muitas vezes em dificílimas batalhas, sentiram como auxílio e defensor máximo ${ }^{17}$.

Depois, quando cresceu, arrancado às insídias dos seus e alcançado o reino paterno, ilustre quer nas artes da guerra, quer nas da paz, atacou violentamente as forças dos sarracenos. Tomou, pela força, a ilha maior das Baleares; a menor, fê-la submeter a um tributo, pelo terror da guerra; subjugou Ebuso às suas ordens. No continente, por outro lado, frequentemente lutando armado contra o inimigo, tomou de assalto a nobre cidade de Valência, abundante em toda a espécie de recursos, juntamente com as restantes fortalezas e

17 Toda esta história é contada com muito pormenor por Rui de Pina (1977: 224, 225) o que permite esclarecer a informação de Perpinhão, que parece um pouco elíptica e obscura, sendo que aquele, erradamente, considera este D. Pedro como o terceiro deste nome, quando se trata efectivamente do segundo:

Porque he de saber, que ElRey D. Pedro deste nome ho terceyro, e dos Reys Daraguam ho noveno, cazou com ha Rainha Dona Maria, filha de D. Guilhemo de Mompilher de que ouve hum filho, que ho socedeo dito D. James deste nome o primeyro, e dos Reys Daraguam ho decimo, este D. James, como nas Coronicas Daraguam se affirma, foy concebido ha caso, e seu nome posto por milagre, porque ElRey D. Pedro por sua natural condiçam, ou por seu vicio era muito dado às molheres estranhas, e muito pouquo à Rainha sua molher, ha que por consentimento e hum camareyro delRey escondida, e muy secretamente se lançou de noyte na cama delRey em luguar de huma moça, com que elle tinha affeyçam, e aquella noyte concebeo do marido, e conhecida por elRey, que do caso foy enverguonhado, ella se nom quis alevantar da cama atée ao outro dia muy claro em que de muitas gentes se fez alli vir conhecer, e daquelle proprio dia de que mandou tomar pubriquos testemunhos ha nove mezes pario hum filho, com que ElRey ouve muito prazer, e por devaçam, e mais segurança da sua vida, mandou loguo offerecer ho menino ha huma Egreja, e encomendallo ha Deos.

Preguntando ElRey pelo Officio, ou Psalmos, que se rezavam aho entrar della, foy certifiquado, que ha este tempo hos Sacerdotes cantavam Te Deum laudamus, e daquelle primeyra Egreja ho mandou levar ha outra segunda, onde pela mesma maneyra soube, que aho entrar della com ho menino se dizia Benedictus Dominus Deus Israel, e sendo ambos pay, e mãy em consulta do nome, que lhe poriam, ha Rainha sua madre dice, que sua vontade, e devaçam era parindo filho, que ouvesse ho nome de cada hum dos doze Apostolos, e para esso mandou loguo fazer doze candeas de cera por igual medida, e pezo, e em cada huma hum escrito, e em cada hum escrito ho nome de cada hum dos doze Apostolos, e com ellas juntas, e ha hum proprio momento acezas mandou dizer huma Missa solene do Espirito Santo, e no cabo della has candeas todas arderam, salvo ha que em nome de SanTiaguo foy posta, que fiquou mais inteyra, e por esso no seu nome de James(...) 
castelos deste reino. Expulsou também, juntamente com Afonso, designado rei de Castela, os sarracenos do reino de Múrcia, o qual está voltado para o mar Ibérico, entre os reinos de Valência e Granada. Na verdade, como aquela parte da Hispânia tivesse sido atribuída aos reis castelhanos, o que fora recebido pelas armas, foi-lhes restituído; ele próprio reservou para si a glória da fortaleza e da habilidade e o fruto sempiterno de tão piedoso esforço. Naquela época, na verdade, diz-se que aconteceram muitas coisas de forma divina a este rei singular, graças à sua piedade. Por um lado, quando um número muito reduzido de cavaleiros, enviado para o território valenciano, abateu, graças aos auxílios celestes e ao terror divinamente inspirado, uma quase incontável multidão de inimigos que se lançara contra eles, vinda de repente de todo o lado, ficando eles próprios incólumes; por outro lado, no próprio cerco da cidade, indo visitar um certo comandante de entre os seus, que jazia na sua tenda por causa de um ferimento, diz- se que arrancara a seta com a sua própria mão e, com um pedaço de tecido molhado na água fria e colocado na perna, curara a ferida.

Viveu oitenta e dois anos em trabalhos continuados, reinou cinquenta e oito, foi querido para os seus, admirável para os estrangeiros, temível para os inimigos, fortíssimo defensor da religião, por cujo interesse em aumentá-la se diz que fez levantar e ornar aproximadamente dois mil templos, parte nas ilhas, parte no continente, recebidos dos inimigos; isto, para além daqueles domicílios que edificou para as santíssimas congregações quer de homens, quer de donzelas. $\mathrm{Na}$ extrema velhice, tendo tomado o hábito dos monges cistercienses e abdicado do poder, com o maior sofrimento dos seus e com grande dor da Hispânia, partiu desta vida; foi levado por três rainhas, das quais uma era sua filha e duas suas noras, e por dois reis, seus filhos, que acompanhavam o funeral.

Depois de morto, pela bondade da sua vida, foi considerado santo; pela virtude militar, grande conquistador; pelos prósperos sucessos das guerras, afortunado; por tudo isto, na sua totalidade, rei de boa memória para a posteridade; o cognome ficar-lhe-á para a eternidade. E de direito terá acontecido isto certamente, que, por um lado, pelos castigos dos ímpios, se produzam para a posteridade severíssimos exemplos para os restantes, e por outro, pela vida dos bons concluída com uma morte desejável, os restantes sejam convidados a imitá-la. ${ }^{18}$

18 Perpiniani 1749: $2^{\circ}$ 173-175

Rui de Pina 1977: 225 apresenta uma informação mais reduzida sobre estes aspectos, pelo que Perpinhão terá usado informação também (provavelmente) nas crónicas aragonesas:

E este Rey D. James foy ho que tomou segunda vez Valença Daraguam aos Mouros por cerquo, e força, porque da primeyra vez, que por ho Cide Ruy Dias foy 
Ao pai e à mãe de $\mathrm{D}$. Isabel é também dado o devido destaque. D. Pedro III (1239-1285), cognominado o Grande, foi rei de Aragão, Catalunha e Valência. Por ter casado com D. Constança, filha de Manfredo e herdeira do trono da Sicília, D. Pedro autoproclamou-se rei da Sicília, passando a governar com o consentimento da esposa, após o que foi excomungado pelo Papa Martinho IV. Perpinhão destaca a actuação destas duas figuras, nomeadamente no desempenho relacionado com a disputa da Sicília. D. Pedro, a quem os sicilianos tinham dado, pois, o trono da Sicília, pois pertenceria, de direito, a sua esposa, D. Constança, defrontou-se com Carlos de Anjou; nesta guerra, surgiu esta situação, contada por Perpinhão de forma elíptica, mas bastante desenvolvida em Rui de Pina. Carlos de Anjou deixara seu filho por governante da Sicília, mas este foi capturado por um Almirante dos reis aragoneses, Rogério de Láuria, o que causou o desgosto e morte do pai e a completa sublevação dos sicilianos contra os franceses ${ }^{19}$. Nele se distingue D. Constança pela sua moderação, ponderação e noção de justiça (vd. supra).

Na sequência de conflitos entre D. Pedro III e Carlos d'Anjou, arbitrara-se um encontro entre os dois reis, acompanhados de 100 soldados cada um, para se resolver a questão. O desafio realizar-se-ia em Bordéus, em território neutro, mas D. Pedro supostamente apareceu disfarçado,

tomada, elles Mouros no proprio tempo de sua morte ha tornaram ha cobrar, e atée este Rey ha tiveram. E este Rey D. James depois de muito velho, e nom podendo jáa sofrer o pezo, e carreguo do regimento de seu Reyno fez alevãtar, e obedecer por Rey aho Ifante D. Pedro seu filho, e elle meteose Monge no Moesteyro de Santa Cruz, de Monges branquos, onde jáas sepultado.

19 Fonte: Rui de Pina 1977: 228:

(...) hos de Mecina, porque eram por este caso apertados pelo Papa com grandes escõmunhões, e antreditos sabendo ha morte delRey Carlo por mais sua vingança se foram ahos carceres, onde estavam hos Francezes para hos matarem, e porque os prezos eram homens, e bons Cavalleyros se poseram em defençam, e resistencia, $e$ foram dos Cezilianos nos mesmos carceres mortos sem piedade, e queymados, e assi quizeram fazer aho Principe Carlo, se ha Rainha Dona Costança molher delRey D. Pedro, que ha esse tempo era em Cezilia, lhe nom valera, porque estranhou fazerse tam crua justiça, sem mandado, nem autoridade delRey D. Pedro seu marido, e dally concordaram, que Carlo fosse levado preso, como foy Araguam, onde era, e avendo quatro annos, que ho dito Carlo era prezo depois da morte delRey D. Pedro, Reynando em Araguam ElRey D. Affonso deu filho, foy por meio delRey D. Duarte Dingraterra solto sobre ha refens (...). E por esto, e por cazamentos que depois antre elles se fizeram fiquou ahos Reys de Araguam ho direyto no Reyno de Cezilia (...) 
temendo uma cilada; foi ao local combinado, mandou que se fizesse um auto da sua presença e regressou a casa sem ser descoberto. Perpinhão seguiu esta informação; mas como tem outras, diferentes, apresenta-as também. Depois de prolongada guerra e graças a conflitos internos entre os franceses, a coroa da Sicília acabou por ser entregue a D. Pedro III que teve de formar um exército para combater a nova força de tropas francesas de Filipe III, que apoiava a facção de Anjou; em 1285 o rei deposto acabaria por morrer de cólera e, pouco mais tarde, também D. Pedro III adoeceu e morreu, na Catalunha, depois de ter pedido e conseguido o levantamento da excomunhão e confessado fidelidade à Santa Sé. No geral, a sua imagem não sai engrandecida das palavras de Perpinhão, atribuindo até a sua iniquidade aos laços de parentesco que estabelecera ao casar com D. Constança:

Mas Pedro, pela sua virtude e grandeza de espírito, pelo conhecimento das armas não inferior ao de qualquer rei, travou muitas e grandes batalhas prósperas contra o inimigo sarraceno. A piedade e a religião, a pouco e pouco, ao que parece, foram prejudicadas com a nova afinidade com os reis da Sicília e um final triste e digno de lamento, de algum modo, espalhou sombras sobre todas estas façanhas tão admiravelmente executadas.

Com efeito, massacrados os Gauleses pelos Sicilianos, na mesma época, apesar dos protestos veementes do Pontífice Máximo, submeteu toda a ilha à capitulação do poder, em nome da mulher. De seguida, aproximando-se o dia estabelecido para o combate, para, na companhia de cem cavaleiros escolhidos, os dois reis aparentados decidirem pelo ferro o direito universal da Sicília, [aconteceu uma destas situações]: ou não esteve presente abertamente, mas brincando com a religiosidade do juramento, secretamente, junto do Prefeito de Bordéus, onde se devia travar a luta, ou junto de outros, alegou a iniquidade da luta e do lugar e subitamente, em marcha apressada, voltou para casa; ou, então, simulando o medo antes, para que ninguém suspeitasse do que estava para acontecer, determinado o dia, de repente, apareceu armado à vista de todos, montado no cavalo, com voz altíssima invectivando e acusando Carlos ausente, ainda que durante pouco tempo cavalgasse ali à volta, e voltou para os seus em marchas diurnas e nocturnas. ${ }^{20}$

20 Esta passagem obscura pelo espírito sintético de quem considera estes conhecimentos do domínio geral, é clarificada pela leitura de Rui de Pina 1977: 227, 228, 229:

Ha quem ElRey D. Pedro com escuzas coradas das cousas passadas (a exigência do Reyno da Sicília, que pertenceria à mulher) se mandou defender em 
Finalmente, como não só era mantido afastado dos templos e das coisas sagradas, e era tido no número dos ímpios e dos celerados, pelos éditos dos Pontífices, como também, espoliado do nome e honrarias de rei, fosse combatido como desertor da religião ou um qualquer sarraceno, enquanto se esforçava por resistir, com mais ânimo do que forças, aos exércitos dos gauleses que invadiam a Hispânia, com muito poucos recursos (com efeito, completamente abandonados pelos aragoneses, cuja imunidade e instituições tomara a cargo, apenas contava com o auxílio dos catalães, ainda que sofressem dos mesmos males), morreu passados poucos dias, de um golpe recebido.

Os escritores nacionais não fazem menção da ferida. Dizem que morreu de doença, algum tempo depois de capturada Gerona pelo gaulês. Consta que terá morrido sem ter feito pazes com a vontade do Pontífice e que aquela proibição das actividades sagradas terá durado por muitos anos até Bonifácio VIII e ao rei Jaime, seu filho. A verdade é que, estando para morrer, não só expiou os seus pecados, pela confissão, como tomou o santíssimo corpo de Cristo, por conselho de um sacerdote que ele tinha para si, pelas sagradas confissões, ainda que tenha recusado, por um instante, aterrorizado pela consciência daquilo que fizera, contrariando a vontade do Sumo Pontífice ${ }^{21}$.

Roma por seus Embayxadores, hos quaes por guanharem tempo, e escuzarem ha yda dos Francezes sobre Cezilia, porque estavam muito poderosos concordáram em nome delRey D. Pedro por juramentos solenes, que a contenda desse Reyno se partisse por desafio dambos hos reys em pessoas, e com cem Cavalleyros cada hum sôomente, e que fosse em Bordeos, que a esse tempo era delRey Dingraterra, e que aho Rey vencedor fiquasse livremente, e sem contradiçam ho dito Reyno de Cezilia, do que ElRey Carlo foy muy contente, para concordarem o desafio (...)

Mas ElRey D. Pedro nom pareceo pubriquo em Bordeos, e porem se diz, que por nom quebrar o juramento, que fizera se mostrou ahi alguns em secreto, $e$ que de como parecera tomou por sua escuza estormentos, e se volveo ha seu Reyno com grande pressa, e por este enguano de que ElRey de França, e Carlo seu tio, e ho Papa juntamente foram muito escandalisados, o Papa escommungou ElRey D. Pedro, e deu contra elle Cruzada, e concedeo ho Reyno Daraguam com grande solenidade, e com grande doaçam ha Felippe Conde de Valois (...)

21 Perpiniani 1749: 20 176-177.

A versão de Perpinhão, quanto à morte de $\mathrm{D}$. Pedro, apoia-se também em Rui de Pina 1977: 228 que, por sua vez, invoca as crónicas francesas e aragonesas:

E por esto, e por cazamentos que depois antre elles se fizeram fiquou ahos Reys Daraguam ho direyto no Reyno da Cezilia; como quer que sobre esta mesma contenda antes de se fazer a mesma concordia ElRey Felippe de França, e este Rey D. Pedro Daraguam faleceram ambos sobre ho cerquo de Girona, ha saber, ElRey de 
Como se pode verificar, é frequente no relato de Perpinhão a apresentação das várias versões dos acontecimentos, recolhidas em fontes diversas. O seu amor e manifesta fidelidade à verdade dos factos leva-o a declará-las todas, para não se tornar suspeito de parcialidade. É também frequente a sua referência aos documentos escritos que consultou, para fundamentar absolutamente aquilo que diz. Verifica-se, por exemplo, quando se pronuncia sobre a má relação entre D. Pedro e o pai, que explica pelo facto de este ter casado, contra vontade daquele, com Constança:

Diz-se que o pai sentiu essa situação com espírito cheio de indignação. E esta terá sido, para ele, talvez, a razão por que nunca mais, até ao último dia da sua vida (o que eu vi afirmado nas letras mais antigas ${ }^{22}$, permitisse que viessem à sua presença, quer o filho, quer os filhos deste ${ }^{23}$.

Se a família da mãe, D. Constança, não lhe merece boas referências, no que diz respeito aos homens, já a do pai é enobrecida e santificada pela piedade do avô, D. Jaime, mas atinge o auge, no campo feminino, com Santa Isabel de Hungria, tia-avó de D. Isabel de Aragão. Isabel, filha de André II da Hungria e de Gertrudes de Andechs-Merano, nascera em 1207 e tinha apenas 4 anos quando o pai aceitou casá-la com o Landgrave da Turíngia, o príncipe Luís IV, sendo então levada para a Turíngia, em 1211, para aí ser educada pela sogra; aprendeu a ler, a escrever, a conhecer os hábitos e costumes da Turíngia e a conviver com uma das cortes mais desenvolvidas de então; o casamento efectivo ocorreu em 1221, tinha Isabel 14 anos. Tinha, como meia-irmã, Violante de Hungria, fruto de segundas núpcias do pai com Violante de Courtenay, princesa de Constantinopla, a qual casou com D. Jaime I de Aragão, pai de D. Pedro III, e, portanto, avó de D. Isabel de Aragão.

A versão adoptada por Perpinhão, sobre a vida de Santa Isabel de Hungria, não corresponde exactamente à versão de outros relatos, nomeadamente hagiológicos, uma vez que não lhe atribui descendência. Com

França por doença, e ElRey D. Pedro por dezemparo, e treyção dos seus, foy morto ha ferro, como nas Coronicas de Frãça e Daraguam mais largamente se decrara.

22 Refere-se provavelmente ao manuscrito que existia em Santa Clara, de autor anónimo, mas escrito logo após a morte de Santa Isabel, Livro que fala da boa vida que fez a Rainha de Portugal, Dona Isabel, e dos seus boons feitos e milagres em sa vida e depoys da morte. Cf. Nunes 1921; 1292-1384.

23 Perpiniani 1749: $2^{\circ} 175$. 
efeito, Santa Isabel e Luís da Turíngia tiveram três filhos, Herman, Sofia e Gertrudes. A sogra, restante família do marido e a corte mostravam-lhe grande hostilidade, por causa da sua humildade e dedicação aos pobres, que manifestava desde pequenina, pelo que, à morte do marido, a caminho da VI Cruzada, Santa Isabel, viúva aos vinte anos, e os seus filhos foram afastados da corte e despojados dos seus bens. Acolheram-se à protecção dos tios da jovem viúva, D. Matilde, abadessa do Convento de Ktizingen, e D. Ekbert, Bispo de Bamberga; foi este que desenvolveu esforços para reconduzir Isabel e os legítimos herdeiros ao trono, solicitando o auxílio dos companheiros de Luís, que regressavam da cruzada e traziam os seus restos mortais. Depois de concretizado este objectivo, Isabel confiou os seus filhos aos cuidados de familiares e retirou-se para Marberga para se dedicar ao auxílio aos pobres; alguns relatos apontam para que terá vestido o hábito de mendicante; outros referem que terá vestido o hábito sem professar, vivendo num paço existente nas imediações do hospital, onde desenvolvia grande parte da sua actividade de assistência. Fundou ou ajudou a fundar hospitais e instituições de apoio social, destinados ao acolhimento e tratamento de doentes, leprosos, idosos, mulheres, órfãos. Morreu em 1231, aos 24 anos; depois de abdicar em favor dos filhos, tinha ingressado na"Venerável Ordem Terceira de Penitência do Glorioso S. Francisco". Foi canonizada em 1235 e estabelecido o dia 19 de Novembro para a comemoração da sua festa solene. São-lhe atribuídos numerosos milagres, quer em vida quer depois da morte. O percurso de Santa Isabel de Portugal assemelha-se, em numerosos momentos e situações, ao de Santa Isabel de Hungria. ${ }^{24}$

Conduzida ao templo para ser banhada com a água sagrada, os pais decidiram chamar-lhe Isabel. Na verdade, alguns anos antes vivera Isabel, filha de André, rei da Panónia, de quem acima falei, irmã de Violante, que Jaime, o avô da criança, como já antes ficou explícito, tomou como esposa; esta, encontrando Conrado ${ }^{25}$, como mestre de costumes, varão da congregação do bem-aventurado Francisco, insigne naqueles tempos não só em sabedoria como também em probidade, tanto mergulhara no zelo de piedade que

24 Cf. Castro, A. P. (ed.) (Novembro de 2007), A coroa, o pão e as rosas. VIII centenário do nascimento de Santa Isabel de Hungria. Coimbra.

25 Conrado de Marburgo, confessor e director espiritual de Santa Isabel de Hungria. Depois da morte desta, compilou todas as notícias que poderiam vir a integrar um processo de canonização, o que aconteceu em 1235, sendo a primeira mulher franciscana canonizada, antes mesmo de Santa Clara. 
parecia um exemplo de todas as virtudes. Casou, por vontade do pai, com Luís, Landgrave da Turíngia (convém, na verdade, alongarmo-nos um pouco mais do que a situação talvez exija, sobre os seus costumes, quer porque foi parente de Isabel, quer porque esta teve este exemplo doméstico para imitar, colocado ante os seus olhos). Tendo sofrido muitos males e muitas injustiças, com extraordinária perseverança, finalmente, ultrapassando as dificuldades, convenceu o marido a levar o mesmo modo de vida, o qual, sendo publicamente um príncipe e, em privado, um companheiro de admirável virtude, permitiu à esposa o livre poder de fazer o que quer que achasse apropriado.

Ela, seguindo a vontade do marido publicamente, fez o voto de conservar o seu corpo casto e íntegro em todo o resto da sua vida. Não permitia que os seus a tratassem por "senhora"; ela própria, dedicando-se ao trabalho das lãs, pernoitava entre as criadas que trabalhavam à noite; a estas, não só as fazia sentar a seu lado, como mandava tirar a comida da mesma travessa que ela; até as tarefas desprezíveis da cozinha, a que as senhoras honestas têm horror, frequentemente desempenhava rindo, com alegria.

A humildade do seu espírito vencera a repugnância da natureza; o desprezo de si, a ambição de glória; o desejo de imitar Cristo, a falsa opinião, imbuídos na qual os homens não apenas tinham já suprimido, noutros tempos, o valor das coisas, como até as verdadeiras palavras. Tolerava as injúrias; na suprema abundância suportava, de sua livre vontade, os incómodos da pobreza; castigava o seu corpo magro e delicado com longos períodos de jejum; dedicava uma boa parte do tempo diurno e nocturno às orações sagradas e à contemplação das questões celestiais, na qual, por vezes, de tal forma mergulhava em divina suavidade, de tal forma se abstraía do sentido do corpo, que não sentia a chama nas suas roupas a arder, por qualquer acidente, a não ser que fosse acordada pelos seus.

Depois que o Landgrave partiu de casa para a guerra com o Sírio e morreu em Brindes, sem deixar filhos, como todos os seus bens voltassem, de direito, para os seus parentes e familiares, Isabel, daquilo que recebera na qualidade de dote, fez nascer um hospital público, onde, servindo de forma humilde e submissa, os pobres e os doentes, pedindo esmola para si e para eles, depois de consumidos já os bens em lã e em tecido, sem nojo da sordidez, não receando o contágio das doenças, não se poupando ao trabalho nem aos gastos, nesta santíssima servidão gastou o restante tempo da sua vida.

Ressuscitou 16 mortos; a um homem cego, não por qualquer acidente, mas de nascença, deu-lhe o sentido da visão. Por estas razões, o Pontífice Máximo, o nono desde o primeiro que adoptou este nome, com as maiores cerimónias, de acordo com a opinião comum dos padres purpurados, depois da morte, colocou-a no número dos beatos. 
Assim, a 12 dias das calendas de Dezembro, por costume e instituição da Igreja Católica, em seu nome, cumprem-se não só preces públicas, por todo o lado, como também cerimónias sagradas. E assim, se tivesse seguido a celebridade e a fama mundanas, já hoje estaria completamente caída no esquecimento; fugindo-lhes, alcançou não apenas a vida feliz e eterna que almejava, como também o que desprezava, a imortalidade do nome ${ }^{26}$.

Os exemplos de virtude e santidade são apresentados como exemplos de vida a imitar. Santa Isabel de Hungria é proposta como modelo de santidade a seguir pelos leitores deste relato, mas, mais ainda, como exemplo que já frutificara, pois já fora adoptado por alguém que se distinguira igualmente nos mesmos valores e modo de vida, a sobrinha-neta, a, então, ainda, bem aventurada Isabel de Portugal. Ambas receberam o reconhecimento da posteridade pelos seus admiráveis percursos de uma vida dedicada aos outros e à assistência aos mais desprotegidos da sociedade.

Os exemplos de maldade, por seu lado, são apresentados como exemplos a evitar, pois são sempre objecto de castigo. Veja-se, já não entre os antecedentes, mas entre os descendentes da Rainha, a opinião negativa de Perpinhão sobre D. Afonso IV que, pela guerra continuada que moveu contra o pai, D. Dinis, viu também o seu próprio filho, D. Pedro, mover-lhe uma guerra feroz a si:

Mas Deus, severíssimo vingador dos crimes e defensor da dignidade do pai, não permitiu que aquela ferocidade juvenil ficasse impune e livre, e, assim, do mesmo modo em que ele próprio fora perigoso para Dinis, assim recebeu em recompensa, depois de velho, penas mais atrozes, dignas de tamanho crime. Com efeito, seu filho Pedro, herdeiro do trono, a quem os feitos deram o cognome de Cru, depois da morte da esposa, Constança, teve abertamente com o nome de amante, uma certa Inês, de linhagem, de cognome Castro, em quem já antes tinha pousado os olhos, e dela teve filhos. Como Afonso a mandasse matar, receando que ocultamente alguém desse veneno a seu neto Fernando, para que o trono fosse herdado pelos filhos dela, aquele (Pedro) furioso de dor e enlouquecido, associando-se a dois irmãos dela, que dominavam em Castela, numa vasta região, congregou muitos criminosos, reunidos de todo o lado; começou uma guerra funesta contra o pai; atacou com muita hostilidade aquela parte de província Tarraconense, que, só unida à Lusitânia, está limitada pelos dois rios, Douro e Minho. Com a reconciliação das partes, enfim, seguiu-se que, para onde quer que se dirigisse, tinha o poder e última decisão; exercia o reconhecimento não

26 Perpiniani 1749: $2^{\circ} 179-181$. 
só dos assuntos privados, como dos públicos; podia matar, mandar para o exílio, punir os condenados com o confisco dos bens; pronunciava cartas, éditos, decretos; tinha o poder de decisão dos juízes, que seriam superiores a todos os julgamentos do rei e aos prefeitos das cidades. Isto não aconteceu injustamente, que o filho the apontasse as armas, a ele que, tantas vezes, tivera a mão armada contra o pai, e vivo ainda, repôs-se a ordem, pois ele, de algum modo, tentara espoliar seu próprio pai do reino. ${ }^{27}$

Quando compôs esta biografia da rainha D. Isabel, Perpinhão tinha em mente as regras do labor do historiador, de acordo com os autores clássicos, como Cícero, Salústio ou Tucídides, adoptadas também pelos seus contemporâneos. A sua maior preocupação prende-se com a fidelidade à verdade dos factos, o que o leva a fazer alusão frequentemente às fontes escritas consultadas, para creditar o relato; é essa preocupação também que o leva, na presença de mais do que uma versão dos acontecimentos, a referi-las todas, para não cair em suspeita de parcialidade. A história assume também, pelas suas palavras claras de crítica ou de louvor, uma função pedagógica, quando destaca os castigos sofridos pelos que praticaram o mal e as recompensas merecidas pelos que se dedicaram ao bem e, assim, se tornaram exemplos de vidas a evitar ou a seguir, respectivamente.

\section{Bibliografia}

Andrade, M.F. (2012), Rainha Santa, mãe exemplar. Isabel de Aragão. Lisboa.

Castro, A. P. (ed.) ( Novembro de 2007), A coroa, o pão e as rosas. VIII centenário do nascimento de Santa Isabel de Hungria. Coimbra.

Enciclopédia Luso Brasileira de Cultura (Verbo). Lisboa.

Gaudeau, B. (1891), De Petri Ioannis Perpiniani uita et operibus(1530-1566). Paris.

Grande Enciclopédia Portuguesa e Brasileira. Lisboa. Rio de Janeiro.

Lazeri, P. (1749), De Vita et Scriptis Petri Ioannis Perpiniani Diatriba. Roma.

Nunes, J.J. (1921), “Vida e milagres de Dona Isabel, Rainha de Portugal”, Boletim da Classe de Letras, 13: 1292-1384.

Perpiniani, P. I. (1749), Opera ( $1^{\circ}, 2^{\circ}$ e $3^{\circ}$ volumes). Roma.

Pina, R. (1977) Crónicas (D. Sancho I, D. Afonso II, D. Sancho II, D. Afonso III, D. Dinis, D. Afonso IV, D. Duarte, D. Afonso V, D. João II. Introdução e revisão de M. Lopes de Almeida. Porto.

27 Perpiniani 1749: 2º 287-288.

Humanitas 66 (2014) 367-388 
Pizarro, J.A.S.M. (2008), D. Dinis. Lisboa.

Soares, N.C. (1992), "Humanismo e História: ars scribendi e valor do paradigma", Máthesis 1: 153-169.

Teixeira. A. J. (1899), Documentos para a História dos Jesuítas em Portugal. Coimbra.

Toipa, H. C. (2011), "O percurso de Pedro João Perpinhão em Portugal”, Humanitas, 63: $405-426$

Vasconcelos, A. (1891-1894), Evolução do culto de Dona Isabel de Aragão, esposa do rei lavrador, D. Dinis de Portugal (a Rainha Santa),(2 volumes). Reprodução fac-similada. Prefácio e Introdução de Manuel Augusto Rodrigues (1983) Coimbra. 